IJ§ER

ISSN: 2149-5939
International Journal of Social Sciences and Education Research

Online, http://dergipark.gov.tr/ijsser

Volume: 3(4), 2017

\title{
Children's experiences of engaging with ICT in learning EFL: A case study from Saudi Arabia
}

\author{
Safana Aseri ${ }^{1}$
}

Received Date: 10 / 03 / 2017

Accepted Date: 12 / $06 / 2017$

Abstract

Within last decade there has been a push for use of ICT based education tools across all levels. However, there has been a lack of research on how ICT interventions affect students' ability to learn. For young children the focus need to be on improving experience of learning and boosting their learning skills. This paper looks at how ICT intervention affect Saudi preschool school children's experience of learning English as Foreign Language (EFL). Data was collected using English test scores and student observation. Findings of this paper indicate that ICT can be useful in teaching EFL but it need to be used keeping in mind the abilities of the students.
\end{abstract}

Keywords: ICT intervention in teaching EFL, ICT and learning EFL, Learning EFL in Saudi Arabia

\section{Introduction}

In 2000s Saudi government started to look for ways to make the country modern and competitive (Alnofai, 2014). In a globalised world the knowledge of English was seen as one of the key ingredient for success, for both organisations and individuals (Faruk, 2014).

Within last two decades, Saudi Arabia has been looking to invest significantly in education especially in modern and scientific education. Aligning Saudi education system with the global system is one of the key objectives in this regard. Teaching of English as foreign language (EFL) at early stage in child education is seen critical component of this education reform plan (Alnofai, 2014). Saudi Arabians now view English as the one universal language of modernization, sciences, and high economic status, making English a requirement for the labor market (Faruk, 2014). However, the current state of teaching EFL is seen as poor due to reasons such as poorly trained teachers (Alharbi, 2015), use of methods such as Grammar-Translation and the use of Arabic as a language of instruction, use of deductive methods (Assalahi, 2013). Use of modern technology is seen as one of the solutions to improve the quality of learning of EFL in Saudi Arabia (Alharbi, 2015). Alfahad (2009) conducted a study on Saudi Arabian students and concluded that technology is likely to enhance the communication skills, and change students from passive learners to more communicative learners.

Several studies have confirmed that use of ICT can be useful in language teaching and learning (Hubbard, 2013; Kean, Embi, and Yunus, 2012; Jung, 2006). Use of ICT helps individuals in developing their creative abilities, problem solving skills and critical thinking ability (Hubbard, 2013; Kean et al., 2012; Klimova and Semradova, 2012). ICT also gives unrestricted access to

\footnotetext{
${ }^{1}$ University of Roehampton, London, United Kingdom, aseris@roehampton.ac.uk 
Aseri, S. (2017). Children's experiences of engaging with ICT in learning EFL: A case study from Saudi Arabia. International Journal of Social Sciences and Education Research, 3(4), 1090-1103.

global repository of information and knowledge which has become even easier with ubiquity of communication mediums such as smartphone.

This study focuses on the use of ICT in the learning of EFL in Saudi Arabia. This study is anchored on the recent attempts of the Saudi government to introduce English as a subject in the curriculum of elementary education subsequently attesting to the increasing importance of teaching EFL to younger students.

\section{Literature}

\subsection{Theoretical overview}

According to Piaget's constructivist theory, child-determined exploration and guided discovery, as opposed to direct teaching, serve as the basis for learning. In addition, Ciampa (2012, pp. 3-4) asserted that "the constructivist goals of learner control, autonomy support, choice, active problem-solving, and use of relevant and authentic texts in beginning reading instruction are preferred to explicit, teacher-directed instruction." Thus, Piaget's constructivist theory underpins the stated benefits of ICT use in educational settings. In particular, it is reflected in Weber's claim that (2011, p. 565) ICT provides "better access, more control, and greater freedom for e-learners"; as well as in Sharples et al.'s (2009) view that children need to cultivate a reflective, 'metacognitive awareness' (meaning an understanding of their own learning processes) of their own creative and safe engagement with ICT.

Similarly, Vygotsky's (1978) Social Constructivism Theory posits that social aspects or factors such as friendships and a sense of togetherness are important to learning. Social interaction plays a key role in the development of cognitive skills (Chung, 2012). Chung (2012) explained that Vygotsky (1978) subsequently developed the 'Zone of Proximal Development' (ZPD) theory to further illuminate the reason behind the positive effect of social interaction on an individual's cognitive development.

ICT tools are viewed as devices that enhance social interaction and child play when applied in educational settings (Gahwaji, 2011). Plowman and Stephen (2005) also found that there is a positive relationship between play and learning, highlighting the advantages of introducing children to ICT at an early age. These findings strongly support the assumptions behind Piaget's Constructivist Theory as well as Vygotsky's (1978) Social Constructivism Theory.

Communicative Language Teaching is focused on achieving holistic communicative competence, including linguistics and adequate grammar skills. It focuses on aspects such as fluency and context meaningfulness and aims to consider language in functional terms. It thus, suggests that productive use is more critical than accurate use of language (Brown, 2007). This view is also supported in the Discourse Approach (Cots, 1996) which suggest that promoting discourse based teaching can help students in acquiring strong communication skills. It thus supports the use of real life materials for teaching language. The aim is not only to improve linguistic abilities but also communicative and pragmatic competence. This means engaging is a discussion in a group, taking turns to listen and talk based on what has been heard. This is likely to help students learn and apply foreign language (Celce-Murcia and Olshtain, 2005). 
Aseri, S. (2017). Children's experiences of engaging with ICT in learning EFL: A case study from Saudi Arabia. International Journal of Social Sciences and Education Research, 3(4), 1090-1103.

\subsection{ICT and teaching EFL}

Several authors have defined ICT differently but for the purpose of this research the definition given by Plowman and Stephen (2005, p.147) is adopted. They defined ICT as various "audiovisual resources, 'smart' toys [...] remote control devices, photocopiers, telephones, fax machines, televisions, and computers, [...] toys that simulate appliances such as mobile phones, laptops, cash registers, microwave ovens, and barcode readers as well as computers [...]."

Within the context of education in general, ICT has been considered capable of supporting basic education (Sanyal, 2001). With particular reference to childhood education, there appears to be a consensus amongst various stakeholders such as policy makers, practitioners, academics, and parents with regards to the positive relationship between play and learning, highlighting the advantages of introducing children to ICT at an early age (Plowman and Stephen, 2005).

Extant literature that delves on the usefulness of ICT in early education is of critical importance to the proposed study since this particular strand of literature can help illuminate the ways in which ICT can be used to facilitate the learning of EFL by young children. For instance, extant literature has documented the utility of ICT in enhancing young children's learning and their experiences with peers (NAEYC, 1996). In the same vein, the immense potential of using computers in benefitting young children's mental development (Haugland and Wright, 1997) as well as the positive effects of using interactive teaching programs on preschool children's literacy development (Gahwaji, 2011) have also been demonstrated in prior studies. Gahwaji, (2011, p. 101) recommended the use of ICT that "allows children to decide pace and direction, and contains sound, voice, and music"; as well as those that feature "open-ended learning tasks with animated routines and directions that can be paused and resumed, or halted, and swift feedback to children in order to nurture their interest."

The use of ICT in educational settings has been described as engaging, enabling and transformative (Clark et al. 2009; Prensky, 2010). The use of ICT in childhood education has been found to enhance both personalisation and collaboration, providing tools and experiences that can help children improve their social and independent learning (O'Hara, 2008). In the early years of education, technology has been found very useful in creating an 'enabling environment', founded on communication and interaction (O'Hara, 2008). This relates to Montessori's (2009, p.6) assertion that child development occurs most effectively within environments conducive to 'exploration, communication and manipulation'. While developing practical skills with technology as they develop, children will also need to cultivate a reflective, 'metacognitive awareness' (meaning an understanding of their own learning processes) of their own creative and safe engagement with ICT (Sharples et al. 2009). This concept has been defined as 'e-confidence' and is a key concern for teachers when planning learning experiences involving ICT. A framework of possibilities for using ICT in early education has been developed by the National College of School Leadership (Blows, 2009). This matrix involves a progressive scale of 'e-words', which describe increasing the utility of ICT in transforming learning and in developing children's thinking skills (Blows, 2009). The integration of ICT into the Early Years must be supported by a comprehensive school e-safety policy (Byron, 2008).

Based on the constructivist point of view, learning is construed as a process of sense-making and meaning-making of the world. It involves knowledge construction by the pupils through the experiences that they have, by relating their own experiences to what they already know, and 
Aseri, S. (2017). Children's experiences of engaging with ICT in learning EFL: A case study from Saudi Arabia. International Journal of Social Sciences and Education Research, 3(4), 1090-1103.

through the guidance that teachers are able to offer them (Department for Education and Skills, 2004). Pupil collaboration, experimentation, reflection and analysis are encouraged through the use of well-suited ICT tools. As a result, they become "more independent, active and responsible learners" (Hennessy, Deaney and Ruthven, 2005, p.2). Hence, ICT is increasingly being acknowledged as tools that support student learning (Pera, 2013).

Several researchers have looked at using technology for teaching foreign languages. Yun (2014) support the use of technology in teaching foreign languages especially through movies and documentaries which use everyday language and are, therefore, useful means of teaching authentic speech. Li and Brand (2009) supported use of songs and music for similar reasons. Ching and Fook (2013) found that graphic literature magnifies the skills of critical thinking if implemented in language curricula and model lesson plans.

\subsection{Research framework}

ICT is useful in developing Metacognitive capabilities which eventually lead to core learning related competencies and consequently improvement in language skills.

Theories such as CLT, MI theory and Discourse Approach suggest that ICT is useful in developing students' Metacognitive skills such as creativity, problem solving, communication, self development etc. It leads to improvement in core competencies; in terms of core competencies for children three core competencies are identified in this research:

Task competency: can the student complete a given task i.e. is he/she aware of what needs to be done.

Process competency: Does the student understand the process that needs to be followed?

Personal competency: Does the student have the personal skills such as being cooperative, work in a team, focus on the task etc.

Figure 1. Research framework.
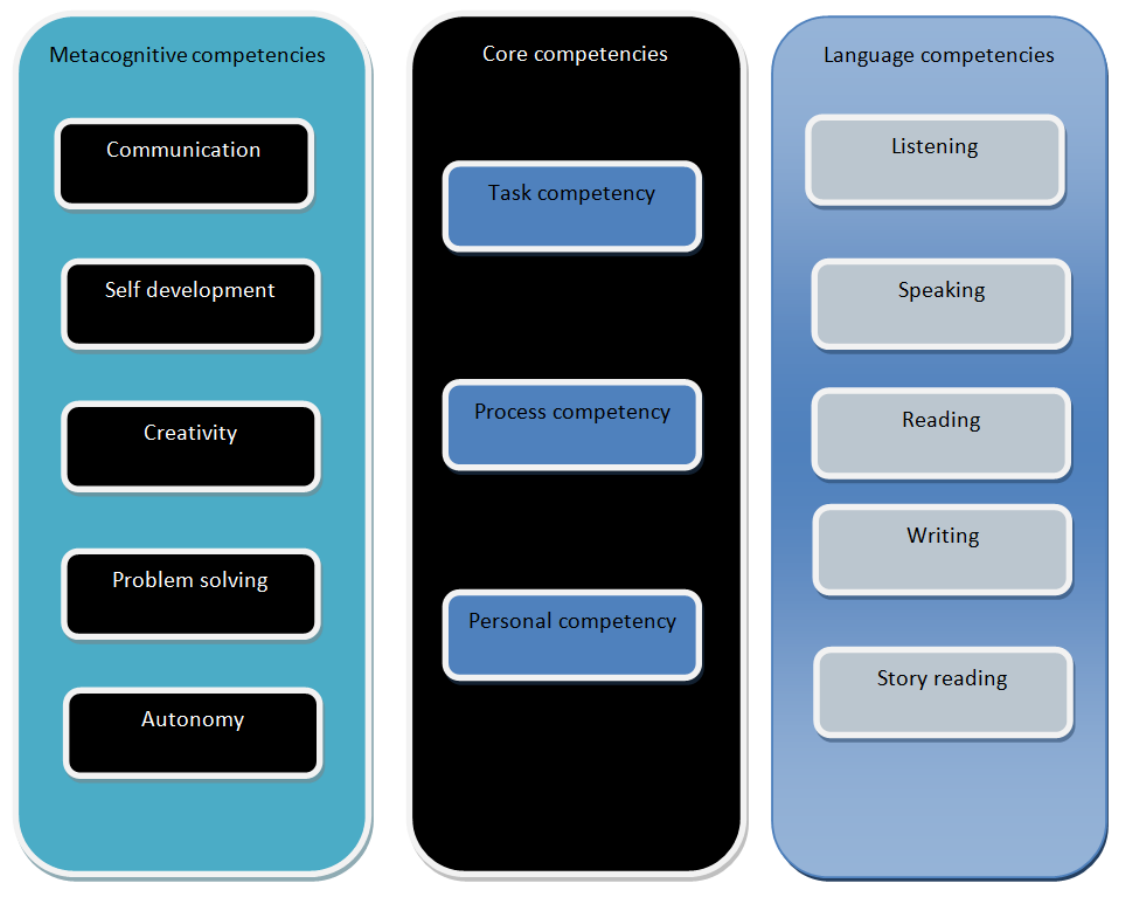
Aseri, S. (2017). Children's experiences of engaging with ICT in learning EFL: A case study from Saudi Arabia. International Journal of Social Sciences and Education Research, 3(4), 1090-1103.

In terms of child's ability to learn a foreign language five key measures were identified. These are: Listening, speaking, reading, writing and reading stories. These are identified on the basis that:

- English as foreign language means that the child has just started to learn English. They cannot be, thus, expected to have advanced English language skills.

- These five are the key skills that most teaching EFL programs focus on.

- These are the skills that children learning EFL are tested on in Saudi Arabian education system. This means new forms of evaluation were not required. This minimised possibilities of errors in evaluation.

\section{Methodology}

\subsection{Method}

This research adopts a mixed methods approach involving a single Saudi Arabian preschool setting in Riyadh. The methods employed include English language testing and classroom observations.

Children's tests (pre-test and post-test) are effective ways of ascertaining the effects of the intervention being investigated (in this case, the effects of the use of ICT tools on the learning of English by the children). There may be differences in the way the students engage with the ICT which would not be visible on a purely quantitative view, differences which might explain certain patterns in the observed results. This can be achieved through observation.

Observation is an effective way of "finding out what people do in particular contexts, the routines and interactional patterns of their everyday lives" (Darlington and Scott, 2002:74).

\subsection{Data collection}

The setting of the study was 'Here to Grow', a private school located in the central urban part of Al Riyadh. The school uses a combination of American curriculum and Arabic National curriculum.

The data collection methods used in this study were: (1) children's tests; and (2) non-participant observation.

\section{1- Children's Tests:}

The children's tests were used to investigate the impact of the usage of ICT tools on their learning of English and subsequently provide support to or evidence against the aforementioned learning theories.

The children's tests included the following: (1) an English Language Test which was administered at the beginning of the second term of the school year, specifically on 25 January 2015 (for children belonging to both Group 1 (G1) and Group 2 (G2); and (2) an English Assessment Test which was administered in the half term, specifically on 22 March 2015, and at the end of the term, specifically 10 May 2015. The English Assessment Test is a standard, in-house test which is actually a grading/rating sheet completed by the teacher. It is used by the school to evaluate the English language skills of pupils from the start of the school year up to the end of the school year. It has five columns - the first four columns correspond to the four grading periods of the entire school year, while the fifth column corresponds to the qualities of the pupils that are being rated by the teacher. The English Language Test measures pupils' skills relating to the following core 
Aseri, S. (2017). Children's experiences of engaging with ICT in learning EFL: A case study from Saudi Arabia. International Journal of Social Sciences and Education Research, 3(4), 1090-1103.

areas: listening and speaking, reading and writing, and reading stories. The English Assessment Test on the other hand, was administered after the ICT intervention.

The children were tested three times during the study in order to know the effect of the ICT intervention. Test scores of each child were obtained for all tests.

\section{2- Non-Participant Observation:}

The present study used non-participant observation to record changes in Metacognitive, core and language skills of children. All G1 members were initially given access to the tablets and the apps with the guidance and instruction of the teachers, whilst no G2 members were provided with tablets. Hence, G2 served as the control group. Then there was a switching over point, wherein G1 members were no longer given access to the tablets. Hence, G1 which was the experimental group at the beginning of the term now became the control group. At this point, all G2 members were given access to the tablets, with the guidance and instruction of the teachers, and hence became the experimental group.

\subsection{Ethics}

Ethical considerations relevant to the present study are centered on the following ethical issues: (1) the use of human participants in the study; (2) privacy for the participants and the confidentiality of the information that they have provided; (3) data protection; (4) the requirement for informed consent of the participants; and (5) vulnerable populations.

To address the first ethical issue, protection of participants from any form of physical or psychological danger during their participation in the study was ensured. This was done by explaining to the teachers and parents of the children-participants what their participation would entail. It was made sure that this information was clearly understood by the teachers and parents of the children-participants.

Furthermore, participants (teachers) and parents of the children-participants were debriefed after conducting the study. All participants (and their parents - in the case of the children-participants) were given the opportunity to decide whether or not to continue with their participation in this study. They were given the prerogative to withdraw at any stage of the investigation; and they were informed of their right to do so.

To address the issue of confidentiality of information about the participants and their respective responses, no further contact with the participants was made after the administration of the research instruments which include the following: (1) the Preschool Evaluation Test and the English Assessment Test; (2) Non-Participant Observation for Children Participants Schedule. In addition, the confidentiality and anonymity of all participants was upheld throughout the research study.

To address the issue of data protection, the collection, storage, disclosure, and use of research data obtained from the participants strictly and fully complied with the Data Protection Act of 1998, which places obligations relevant "to fair and lawful data collection and processing" (Matwyshyn, 2009:238). This was done through the inclusion of the following clauses in the Parents of the Children-Participant Debriefing Form: (a) "The information your child provided will only be used for the research, and will not be disclosed to any third party, except as part of the 
Aseri, S. (2017). Children's experiences of engaging with ICT in learning EFL: A case study from Saudi Arabia. International Journal of Social Sciences and Education Research, 3(4), 1090-1103.

research findings"; and (b) "The data your child provided will be kept and all collected data were stored and pass-worded in author's personal computer.

\subsection{Data analysis}

Data collected for the Children's tests which consisted of test scores for the English Language Test and the English Assessment Test were analysed using a series of multivariate analyses of variance using the general linear model program in Microsoft Excel. Data collected from observation of children participants which consisted of field notes were coded and manually analysed. According to Brophy, Snooks and Griffifths (2008 , p. 136), for less structured observation such as open observation, data "can be coded and analyzed in the same way as the texts of interview transcripts - carefully relating the codes to the evaluation aims and objectives."

\section{Result}

\subsection{Quantitative analysis of test results}

Table 1. t-Test: Paired two sample for means for group A

\begin{tabular}{|l|r|c|}
\hline & \multicolumn{1}{|c|}{ Pre-Test } & \multicolumn{1}{c|}{ Post-ICT } \\
\hline Mean & 32.84615385 & 41.76923077 \\
\hline Variance & 153.974359 & 80.69230769 \\
\hline Pearson Correlation & 0.912493865 & \\
\hline $\mathrm{t}$ Stat & -5.755802054 & \\
\hline $\mathrm{P}(\mathrm{T}<=\mathrm{t})$ one-tail & $4.54017 \mathrm{E}-05$ & \\
\hline $\mathrm{t}$ Critical one-tail & 1.782287548 & \\
\hline $\mathrm{P}(\mathrm{T}<=\mathrm{t})$ two-tail & $9.08034 \mathrm{E}-05$ & \\
\hline $\mathrm{t} C$ ritical two-tail & 2.178812827 & \\
\hline
\end{tabular}

Table 2. t-Test: Paired two sample for means for group B

\begin{tabular}{|l|r|r|}
\hline & \multicolumn{1}{|c|}{ Pre-Test } & \multicolumn{1}{c|}{ Post-Test } \\
\hline Mean & 36 & 39 \\
\hline Variance & 57.75 & 51.36764706 \\
\hline Pearson Correlation & 0.877850623 & \\
\hline $\mathrm{t}$ Stat & -2.971251904 & \\
\hline $\mathrm{P}(\mathrm{T}<=\mathrm{t})$ one-tail & 0.0045016 & \\
\hline $\mathrm{t}$ Critical one-tail & 1.745883669 & \\
\hline $\mathrm{P}(\mathrm{T}<=\mathrm{t})$ two-tail & 0.0090032 & \\
\hline $\mathrm{t}$ Critical two-tail & 2.119905285 & \\
\hline
\end{tabular}

Test results for both Group A and Group B indicate that the pre and post intervention mean test score for the both the groups are statistically different with the post intervention scores higher than the pre intervention score.

Next the scores across the five learning dimensions were compared: 
Aseri, S. (2017). Children's experiences of engaging with ICT in learning EFL: A case study from Saudi Arabia. International Journal of Social Sciences and Education Research, 3(4), 1090-1103.

Table 3. Comparison of means of score for each individual item before and after ICT intervention.

\begin{tabular}{|c|c|c|c|}
\hline \multicolumn{4}{|c|}{ Group A } \\
\hline & Pre ICT intervention & Post ICT intervention & $\mathrm{p}$-value \\
\hline Listening & 7 & 9 & 0.003 \\
\hline Speaking & 5 & 9 & 0.000 \\
\hline Writing & 8 & 8 & 0.048 \\
\hline Reading & 6 & 9 & 0.001 \\
\hline Reading stories & 6 & 7 & 0.068 \\
\hline \multicolumn{4}{|c|}{ Group B } \\
\hline & Pre ICT intervention & Post ICT intervention & $\mathrm{p}$-value \\
\hline Listening & 9 & 9 & 0.103 \\
\hline Speaking & 7 & 8 & 0.073 \\
\hline Writing & 6 & 8 & 0.038 \\
\hline Reading & 7 & 8 & 0.042 \\
\hline Reading stories & 7 & 6 & 0.088 \\
\hline
\end{tabular}

Data indicates that for group A scores across four dimensions improved as a result of the ICT intervention while the score for writing remained the same. However, the change in score for 'reading stories' was statistically not significant. For group B, scores across three dimensions improved while score for 'listening' remained the same and score for 'reading stories' actually declined after the intervention. However, only the rise in scores for writing and reading were found statistically significant.

\subsection{Qualitative analysis of observation data}

In total 1071 observation items were noticed. These items were categorised according to different themes that they belonged to.

Table 4. Frequency of different themes in the observation data.

\begin{tabular}{|l|c|c|}
\hline & Number of observations & \% of total observations \\
\hline Communication & 55 & $5.14 \%$ \\
\hline Self development & 79 & $7.38 \%$ \\
\hline Creativity & 137 & $12.79 \%$ \\
\hline Problem solving & 87 & $8.12 \%$ \\
\hline Autonomy & 123 & $11.48 \%$ \\
\hline Personal competency & 109 & $10.18 \%$ \\
\hline Task competency & 30 & $2.80 \%$ \\
\hline Process competency & 30 & $2.80 \%$ \\
\hline Listening & 101 & $9.43 \%$ \\
\hline Speaking & 78 & $7.28 \%$ \\
\hline Writing & 73 & $6.82 \%$ \\
\hline Reading & 90 & $8.41 \%$ \\
\hline Reading stories & 79 & $7.38 \%$ \\
\hline
\end{tabular}


Aseri, S. (2017). Children's experiences of engaging with ICT in learning EFL: A case study from Saudi Arabia. International Journal of Social Sciences and Education Research, 3(4), 1090-1103.

The table indicates that most of the observations were for creativity followed by autonomy and personal competency. In fact in some cases these two themes were found to be overlapping with each other. In autonomy most common observation was that after the first session most of the students were able to look for certain pieces of information online without assistance. In addition, many of the students were able to also look for additional relevant information.

\subsubsection{ICT and meta cognitive competencies:}

One of the key objectives of ICT is to improve the meta cognitive competencies such as autonomy, creativity and problem solving capabilities of students. Development of these meta cognitive competencies is critical not only for English language learning but also for overall academic development of students.

Communication: Student observation found that interpersonal communication between students decreased as a result of use of ICT. When they had no ipad they were seen chatting, forming groups and engaging in activities. However, when once they were handed over ipads most of the students seemed too absorbed by working on the ipad. The level of communication between the students decreased substantially while using ipad. While in other group exercises students were seen playing with each other, during the use of ipad this aspect was missing.

Out of the 17 students in group A, only 9 instances of communication were noted during the first hour when students were given ipads. In case of group B which consisted of 13 students the number of such instances were slightly higher at 11 but the quality of that communication was poor in the sense that the students only spoke briefly. This indicates that ipad based learning may lead to more individualised behaviour.

Self development: Use of ipads did leave to some degree of self improvement but this was not significant enough to suggest that use of ipads will definitely lead to improvement in self development. There was a decline in team working and cooperation. However, students were able to stay calm and focused on the task. Students' Persistence to learn about particular topic improved significantly after introduction of iPad. Students continued to look for interesting topics and there was a degree of persistence in learning.

Creativity: Creativity of the individuals seemed to improve as a result of the use of ipad. Individuals were seen as more creative; for instance one of the students, who was confused between whether to choose a lion or a tier as his favourite animal, ended up finding information on liger (a hybrid between lion and tiger) and instantly claimed it as his favourite animal. He searched for a liger based on his imagination as he has never heard about a liger before. Even his teacher was surprised because even he teacher had never heard of a liger before.

Originality is one of the key aspects of creative Metacognitive competency. There were several instances when students were seen trying for things that they imagined for their minds. For example, one of the students was seen looking for "sky steps" i.e. stairs which go up to the sky and another student was seen looking for "fly boy" i.e. the boy who could fly. All of these concepts were not linked to their studies but rather emerged from their curious minds. Many of these ideas were completely original and some were influenced by the things that they have seen or experienced. This indicates that the use of ipad did improve the metacognitive competency of creativity in the students. 
Aseri, S. (2017). Children's experiences of engaging with ICT in learning EFL: A case study from Saudi Arabia. International Journal of Social Sciences and Education Research, 3(4), 1090-1103.

Problem solving: The problem solving ability of students did seem to improve as a result of use of ipad. Teachers gave many fun exercises for kids to do and it was noticed that with time their performance in problem solving improved. The scores of the apps were noticed and in 26 of the 30 cases the performance of students improved with the use of ipad. These exercises included some math problems and some puzzles.

Autonomy: Use of ipad improves autonomy as witnessed in the observations. Students required instructions on how to use in the first two lessons but by the third lessons students were already aware of how to use ipads and they seemed little interest in the instructions. Ipads allowed the students an environment of self control and this was evident in observations. Individuals were interested in using ipads but they were pursuing their own interests such as looking for information on special powers of superheroes and then role playing as superheroes.

\subsubsection{ICT and Core competencies}

Personal competency: Personal competency refers to the self conceptualisation, autonomy and self direction. Personal competency is essential in order for students to develop their overall learning capabilities. Student observation revealed that personal competencies of students somewhat improved but not all personal competencies were improved as a result of the use of ipad. For example, students exhibited greater autonomy as a result of the use of ipad but their communication, cooperation and team working skills were affected negatively. There were some instances of team working where students were seen helping each other in using ipads but this was purposive and did not turn into social interaction.

Task competency: One of the key aspects of learning is understand the task competency. Task competency of students showed marked improvement as a result of the use of ipads. By the third lecture using ipads, most of the students in group A were able to perform their tasks as instructed. Similar trends were seen in case of group B with most of the students getting adapted to the task by lecture 3. Also, when the teacher made slight alteration to the task, some of the students were able to complete the altered tasks without the need for additional assistance. Some other students were able to complete the tasks by following the individuals who understood what to do. What was interesting was that even the students who misunderstood the task were able to complete the tasks like the previous ones.

Table 5. Results of task competency observations

\begin{tabular}{|l|c|c|c|}
\hline & $\begin{array}{c}\text { Task completed } \\
\text { correctly }\end{array}$ & $\begin{array}{c}\text { Task completed in- } \\
\text { correctly }\end{array}$ & Task incomplete \\
\hline Group A- before ipad lessons & 3 & 7 & 7 \\
\hline Group A- in ipad lesson 1 & 2 & 2 & 13 \\
\hline Group A- in ipad lesson 2 & 4 & 6 & 7 \\
\hline Group A- in ipad lesson 3 & 5 & 7 & 4 \\
\hline Group A- in ipad lesson 4 & 4 & 9 & 8 \\
\hline Group B- before ipad lessons & 0 & 5 & 11 \\
\hline Group B- in ipad lesson 1 & 0 & 2 & 4 \\
\hline Group B- in ipad lesson 2 & 1 & 4 & 3 \\
\hline Group B- in ipad lesson 3 & 4 & 5 & 8 \\
\hline Group B- in ipad lesson 4 & 2 & & \\
\hline
\end{tabular}


Aseri, S. (2017). Children's experiences of engaging with ICT in learning EFL: A case study from Saudi Arabia. International Journal of Social Sciences and Education Research, 3(4), 1090-1103.

For the exercise tasks were arranged in three levels of difficulty based on the complexity of tasks. Most of the students were adapt at completing the tasks of level 1 complexity but only few were able to complete the level 2 complexity tasks by themselves. Some were able to complete it using the help while some others misunderstood. Almost all of the students were able to complete the task incorrectly

Results indicate that most of the students understood the task from start to finish and were able to complete the cycle of task leading to some form of output albeit wrong.

Process competency: In order to test process competency, one test was developed. Students were asked to complete process of different levels of complexity. Results indicate that process competency of some of the students improved as a result of use of ipad but the results were not significant enough to suggest that continuous use of ipad may lead to improvement in process competency of students.

Table 6. Results of Process competency observations

\begin{tabular}{|l|c|c|}
\hline & Process completed & Process incomplete \\
\hline Group A- process complexity level 1 & 11 & 6 \\
\hline Group A- process complexity level 2 & 5 & 12 \\
\hline Group A- process complexity level 3 & 2 & 15 \\
\hline & & 7 \\
\hline Group A- process complexity level 1 & 6 & 13 \\
\hline Group B- process complexity level 2 & 0 & 11 \\
\hline Group B- process complexity level 3 & 2 & \\
\hline
\end{tabular}

The results indicate inconsistency in process competency as a result of the use of ipad. It is possible that with time and continuous use of ipad the process competency of student may improve but based on results it is difficult to say that any such improvements can be attributed to use of ipad. It is understandable that when individuals repeat certain processes they get used to the process and are able to follow the process. This test was aimed at understanding whether the process competency of individuals improved as a result of use of ipad and wanted to eliminate possibility of any improvement due to individuals getting used to the complex processes.

\subsubsection{ICT and Language competencies}

Listening: Use of ipad seemed to improve the ability of students to listen. Out of the 101 instances recorded for listening in 53 instances students listened the word correctly and in another 22 instances the students remembered the word almost correctly. After listening they were able to write it down accurately albeit with some spelling mistakes.

Speaking: Speaking ability of students seemed to improve significantly but observer noticed that the students were finding it difficult to understand the accent of the speaker on their ipad apps but could comfortably understand the teacher. Nevertheless, their speaking ability seemed to improve as a result of using ipads especially after multimedia based sessions.

Writing: There were instances which suggest that use of ipads may help in improving pupil's writing ability. After use of ipad, more students were seen trying to make up spelling of difficult words based on their own constructive abilities. They would break down the words in smaller 
Aseri, S. (2017). Children's experiences of engaging with ICT in learning EFL: A case study from Saudi Arabia. International Journal of Social Sciences and Education Research, 3(4), 1090-1103.

chunks and the create the spelling based on combining those small chunks. There was also noticeable change in their ability to create longer sentences.

Reading: The ability to read showed noticeable improvement. Most of the students were able to read the sentences correctly by the third lesson using ipad. This is also reflected in their improved reading score.

Reading stories: Surprisingly while the reading score showed improvement but the score for reading stories did not improve and in some cases even declined. This was surprising because students seemed interested in listening to the stories. The only explanation for this was the selection of stories which were either not interesting enough or were too long for the students to read.

\section{Conclusion}

The findings of this research indicate that use of ICT may help in improving the learning of EFL for young children in Saudi Arabia but this on its own, may not be a sufficient measure to achieve such improvement. In particular some contextualisation of ICT modules is required to reduced the effort that the teachers and students have to input to utilise ICT for language learning.

It was seen that the use of ICT negatively affects some of the personal skills and this is one of the key issues that many researchers have raised in past as well. This challenge can be overcome with designing of ICT based lessons in a way that it facilitates rather than hinder person skills development especially in terms of cooperation, collaboration and team working.

\section{Reference}

Alharbi, H. (2015), Improving students' English speaking proficiency in Saudi public schools. International Journal of Instruction, 8(1), 105-116

Alfahad, F. (2009), Students' attitudes and perception towards the effectiveness of mobile learning in King Saud University, Saudi Arabia, The Turkish Online Journal of Educational Technology, 8(2), 111-119.

Alnofai, H. (2010), The attitudes of teachers and students towards using Arabic in EFL classrooms in Saudi public schools: a case study. Novitas-ROYAL (Research on Youth and Language), 4(1), 64-95

Assalahi, H. (2013), Why is the grammar-translation method still alive in the Arab world? teachers' beliefs and its implications for EFL teacher education. TPLS, 3(4). doi:10.4304/tpls.3.4.589-599.

Blows, M. (2009), E-words for ICT and classroom creativity, National College of School Leadership. [Online]. Available at: http://future.ncsl.org.uk/ShowResource.aspx?ID=812 [Accessed: 16 March 2017].

Brophy, S., Snooks, H. \& Griffifths, L. (2008), Small-scale evaluation in health: A practical guide. London: SAGE.

Celce-Murcia, M. (2007), Towards more context and discourse in grammar instruction. TESL-EJ, 11(2), $1-6$.

Celce-Murcia, M., \& Olshtain, E. (2005), Discourse and context in language teaching: a guide for language teachers (3rd ed.). Cambridge, UK: Cambridge University Press.

Brown, H. D. (2007), Teaching by principles: An interactive approach to language pedagogy (3rd ed.). White Plains, NY: Pearson Education.

Byron, T. (2008), Safer Children in a Digital World: the Report of the Byron Review. Nottingham: DCSF Publications. 
Aseri, S. (2017). Children's experiences of engaging with ICT in learning EFL: A case study from Saudi Arabia. International Journal of Social Sciences and Education Research, 3(4), 1090-1103.

Ching, H., \& Fook, F. (2013), Effects of Multimedia-Based Graphic Novel Presentation on Critical Thinking among Students of Different Learning Approaches. Turkish Online Journal of Educational Technology, 12(4), 56-66.

Chung, Y. (2012), Schools at home: Parental support for learning Mandarin as a second language. PhD Thesis. London: University of London.

Ciampa, K. (2012), Reading in the digital age: Using electronic books as a teaching tool for beginning readers. Canadian Journal of Learning and Technology, 38(2), 1-26.

Clark, W., Logan, K., Luckin, R., Mee, A. \& Oliver, M. (2009), Beyond Web 2.0: mapping the technology landscapes of young learners. Journal of Computer Assisted Learning, 25(1), 56-69.

Cots, J. (1995), Bridging discourse analysis into the language classroom. Links \& Letters, 3, 77-101

Darlington, Y. \& Scott, D. (2002), Qualitative Research in Practice: Stories from the Field, Buckingham. Open University Press.

Department for Education and Skills (2004), Pedagogy and practice: Teaching and learning in secondary schools, Available from: http://dera.ioe.ac.uk/5679/1/sec_ppt1043804u15using_ict.pdf [Accessed: 26 January 2017].

Faruk, S. M. G. (2014), Saudis' attitude towards English: trend and rationale. PCTS Proceedings (Professional Communication \& Translation Studies), 7(1/2), 173-180.

Gahwaji, N.M. (2011), The effects of using interactive teaching programs on preschool children's literacy development: Case study. Journal of Research in International Education, 7(1), 99-108.

Haugland, S.W., \& Wright, J.L. (1997), Young children and technology: A world of discovery. Needham Heights, MA: Allyn and Bacon.

Hennessy, S., Deaney, R. \& Ruthven, K. (2005), 'Emerging teacher strategies for supporting subject teaching and learning with ICT.' Available from: http://www.educ.cam.ac.uk/research/projects/istl/TiPS0521.pdf [Accessed: 23 August 2016].

Hubbard, P. (2013), Making a Case for Learner Training in Technology Enhanced language learning Environments. CALICO Journal, 30(2), 163-178.

Jung, S.H. (2006), The use of ICT in learning English as an international language. (3222610 Ph.D.), University of Maryland, College Park, United States - Maryland, ProQuest Dissertations \& Theses A\&I database, Available from http://search.proquest.com/docview/305302616?accountid=10499.

Kean, A. C., Embi, M. A., \& Yunus, M. M. (2012), Incorporating ICT Tools in an Active Engagement Strategy-based Classroom to Promote Learning Awareness and Self-monitoring. International Education Studies, 5(4), 139-149.

Klimova, B. F., \& Semradova, I. (2012), The teaching of foreign languages and ICT. Procedia Technology, 1(0), 89-93. doi: http://dx.doi.org/10.1016/j.protcy.2012.02.017

Li, X., \& Brand, M. (2009), Effectiveness of music on vocabulary acquisition, language usage, and meaning for mainland Chinese ESL learners. (Undetermined). Contributions To Music Education, 36(1), 73-84.

Matwyshyn, A. M., (ed.) (2009), Harboring data: Information security, law, and the corporation. Stanford, CA: Stanford University Press.

Montessori, M. (2009), The Absorbent Mind, Revised ed., Thousand Oaks, CA: BN Publishing.

O'Hara, M. (2008), Young children, learning and ICT: a case study in the UK maintained sector. Technology, Pedagogy and Education. 17(1), 29-40.

Plowman, L. \& Stephen, C. (2005), Children, play, and computers in pre-school education. British Journal of Educational Technology, 36(2), 145-157.

Prensky, M. (2010), Teaching Digital Natives: Partnering for Real Learning. London: SAGE.

Sanyal, B.C. (2001) 'New functions in higher education and ICT to achieve education for all.' In: Proceedings from the Expert Roundtable on University and Technology -for -Literacy/ Basic Education 
Aseri, S. (2017). Children's experiences of engaging with ICT in learning EFL: A case study from Saudi Arabia. International Journal of Social Sciences and Education Research, 3(4), 1090-1103.

Partnership in Developing Countries, International Institute for Educational Planning. Schools: Examples, Experiences and Issues. London.

Sharples, M., Graber, R., Harrison, C. \& Logan, K. (2009), E-Safety and Web 2.0 for children aged 1116. Journal of Computer-Assisted Learning, 25(1), 70-84.

Vygotsky, L. (1978), Mind in society. London: Harvard University Press.

Weber, A.S. (2011), Cloud computing in education in the Middle East and North Africa (MENA) region: Can barriers be overcome?, Conference proceedings of eLearning and Software for Education (eLSE), 2011(01), 565-570.

Yun, E. (2014), Teaching Arabic to Korean students using films. The New Educational Review, 37(3), 8091. 